\title{
Mild clinical behaviour of Crohn disease in elderly patients in a Latin American country: A case-control study
}

\author{
Jesús K Yamamoto-Furusho MD PhD MSc ${ }^{1,2}$, Andrea Sarmiento-Aguilar MD ${ }^{1}$
}

\begin{abstract}
JK Yamamoto-Furusho, A Sarmiento-Aguilar. Mild clinical behaviour of Crohn disease in elderly patients in a Latin American country: A case-control study. Can J Gastroenterol Hepatol 2015;29(8):435-439.
\end{abstract}

BACKGROUND: Crohn disease is characterized by fluctuating clinical behaviour, which is influenced by various factors. There are no data from Latin America that evaluate the clinical behaviour of Crohn disease in elderly patients.

OBJECTIVE: To evaluate the clinical course of elderly onset Crohn disease compared with younger onset in the Mexican population.

METHODS: The present analysis was a case-control study that included 132 patients with a histopathological diagnosis of Crohn disease between 1983 and 2013 in an inflammatory bowel disease clinic of a tertiary care centre. Statistical analysis was performed using SPSS version 17 (IBM Corporation, USA) and descriptive statistics, $\chi^{2}$ and Fisher's exact test for categorical variables and Student's $t$ test for numerical variables. Univariate and multivariate analysis were performed to identify associated risk factors and OR was calculated. RESULTS: A total of 132 patients ( 73 men and 59 women) were divided into two groups according to age at diagnosis: 27 cases ( $>60$ years of age) and 105 controls ( $\leq 60$ years of age). Factors influencing the clinical course of Crohn disease in the elderly were: female sex (OR 2.55 [95\% CI 1.06 to 6.10]; $\mathrm{P}=0.02$ ); colonic location (OR 0.22 [95\% CI 0.03 to 0.89 ]; $\mathrm{P}=0.02$ ); mild clinical behaviour of disease (OR 10.08 [95\% CI 3.74 to 27.17]; $\mathrm{P}=0.0001$ ); response to medical treatment (OR 2.85 [95\% CI 1.08 to 7.48]; $\mathrm{P}=0.02$ ); frequent use of sulfasalazine (OR 4.46 [95\% CI 1.22 to 16.28$]$; $P=0.03$ ); less use of azathioprine (OR 0.38 [95\% CI 0.13 to 1.03 ]; $\mathrm{P}=0.04$ ); and longterm remission (OR 4.96 [95\% CI 1.70 to 14.48 ]; $\mathrm{P}=0.002$ ).

CONCLUSION: Elderly patients with Crohn disease had a mild clinical course characterized by the lack of escalation to immunosuppressive and anti-tumour necrosis factor therapy, as well as long-term remission.

Key Words: Clinical behaviour; Crohn disease; Elderly; Geriatric

Tnflammatory bowel disease (IBD) includes Crohn disease (CD) and ulcerative colitis (UC). Little is known regarding its multifactorial and etiopathogenic mechanisms, of which three main factors - genetics, immunity and the environment - are involved (1). The course of CD is characterized by fluctuating clinical behaviour, which is influenced by various factors including hospitalization rates, treatment response, postsurgical recurrence, relapses, exacerbations and older age at diagnosis.

In 2014, the world's population was estimated to be 7.2 billion and, from this number, $8 \%$ appeared to be older adults (2); however, by 2050 , the number of older persons worldwide is projected to more than double to two billion (3). Population aging is occurring in every country,
Le comportement clinique bénin de la maladie de Crohn chez les patients âgés d'un pays d'Amérique latine : une étude cas-témoins

HISTORIQUE : Le comportement clinique de la maladie de Crohn fluctue en raison de divers facteurs. Aucune donnée en provenance d'Amérique latine ne l'évalue chez les patients âgés.

OBJECTIF : Évaluer l'évolution clinique de la maladie de Crohn qui se manifeste chez les personnes âgées par rapport à celle qui se manifeste chez des personnes plus jeunes au sein de la population mexicaine.

MÉTHODOLOGIE : La présente analyse était une étude cas-témoins composée de 132 patients ayant obtenu un diagnostic histopathologique de maladie de Crohn entre 1983 et 2013 au sein de la clinique de maladies inflammatoires de l'intestin d'un centre de soins tertiaires. Les chercheurs ont procédé à l'analyse statistique au moyen de la version 17 du SPSS (IBM Corporation, États-Unis), ont établi les variables qualitatives au moyen des statistiques descriptives, du test du $\chi^{2}$ et du test exact de Fisher et ont établi les variables numériques à l'aide du test $t$ de Student. Ils ont effectué des analyses univariée et multivariée pour déterminer les facteurs de risque connexes et ont calculé le risque relatif.

RÉSULTATS : Au total, 132 patients ( 73 hommes et 59 femmes) ont été répartis entre deux groupes en fonction de leur âge au diagnostic, soit 27 cas (plus de 60 ans) et 105 sujets témoins (60 ans ou moins). Les facteurs qui influaient sur l'évolution clinique de la maladie de Crohn chez les personnes âgées étaient le sexe féminin (RR 2,55 [95\% IC 1,06 à 6,10]; $\mathrm{P}=0,02$ ), le foyer dans le côlon (RR 0,22 [95 \% IC 0,03 à 0,89]; $\mathrm{P}=0,02$ ), le comportement clinique bénin de la maladie ( $R R$ 10,08 [95 \% IC 3,74 à 27,17]; $\mathrm{P}=0,0001$ ), la réponse au traitement médical (RR 2,85 [95 \% IC 1,08 à 7,48]; $\mathrm{P}=0,02$ ), l'utilisation fréquente de sulfasalazine (RR 4,46 [95 \% IC 1,22 à 16,28]; $\mathrm{P}=0,03$ ), la moins grande utilisation d'azathioprine (RR 0,38 [95\% IC 0,13 à 1,03]; P=0,04) et la rémission prolongée (RR 4,96 [95 \% IC 1,70 à 14,48]; $\mathrm{P}=0,002$ ).

CONCLUSION : L'évolution clinique de la maladie était bénigne chez les personnes âgées, ne s'aggravait pas jusqu'à nécessiter un traitement immunosuppresseur et la prise d'inhibiteur du facteur de nécrose tumorale alpha, et s'associait à une rémission prolongée.

although each country is at a different stage of this transition (4). For example, by 2050, Mexico's aged are projected to represent $27.7 \%$ of the population (5), while the same demographic in the United States is expected to represent $20.3 \%$ (6). This fast-growing elderly population represents part of an age group in which important physiological changes occur, including immune deficiency (peculiar to old age), increased frequency of comorbidities and polypharmacy. These characteristics place this age group at higher risk, which undoubtedly affects the clinical course of CD. Despite the fact that fewer than onethird of epidemiological studies have documented a bimodal distribution of IBD incidence with a second peak between 60 and 70 years of age (7), elderly patients with CD should not be treated with aggressive

${ }^{1}$ Inflammatory Bowel Disease Clinic, Department of Gastroenterology. Instituto Nacional de Ciencias Médicas y Nutrición Salvador Zubirán, Mexico City, Mexico; ${ }^{2}$ Pan American Crohns and Colitis Organisation (PANCCO)

Correspondence: Dr Jesús K Yamamoto-Furusho, Head of the Inflammatory Bowel Disease Clinic, Department of Gastroenterology, Instituto Nacional de Ciencias Médicas y Nutrición Salvador Zubirán. President of PANCCO: Vasco de Quiroga 15, Colonia Sección XVI, Tlalpan, CP 14000,

Mexico City, Mexico. Telephone 52-55-55733418, fax 52-55-56550942, e-mail kazuofurusho@hotmail.com

Received for publication April 6, 2015. Accepted April 7, 2015 
therapy because it has been proposed that the disease process may not represent the same disease process present in younger patients (8). Furthermore, $10 \%$ to $15 \%$ of patients with IBD will be diagnosed at $>60$ years of age $(9-13)$ (65\% during the sixth decade of life, $25 \%$ during the seventh decade and 10\% during the eighth decade $[12,13])$. Women are more likely than men to be diagnosed with IBD after 60 years of age (14-18), and there is a higher incidence of UC than CD (14). These phenotypic differences among age groups reflect variations in mucosal immune response, composition of the microbiome, genetics and/or environmental risk factors that are not fully understood (18). Interestingly, very-early onset (zero to six years of age) and elderly onset CD are characterized by the predominance of pure colonic disease (L2, according to the Montreal classification) (18-26).

Several studies have proposed that elderly patients diagnosed with CD have a less aggressive clinical course compared with those diagnosed at a younger age. This suggests that gastrointestinal tract changes occur with aging and produce dietary shifts among older individuals, alterations in gastrointestinal motility and gastric $\mathrm{pH}$ due to mucosal atrophy, increased intestinal permeability and changes in the gut microbiota associated with aging that may influence host-inflammatory responses (27-30). For example, the risk for surgery decreases with older age at diagnosis, disease distribution and history of cigarette smoking (31). In CD, the prevalence of diarrhea, abdominal pain, extraintestinal manifestations, weight loss and fever decreases in older or elderly patients $(18,32)$. A large population-based cohort study involving a French population that included 841 IBD patients concluded that the clinical course is mild in elderly onset IBD patients due to disease behaviour, and was reported to remain stable in $91 \%$ of patients with elderly onset CD after a median follow-up period of six years (33). Other studies have concluded that the clinical manifestations of the first flare of $\mathrm{CD}$ are similar in the $>60$ years of age and younger age groups (18), characterized by the predominance of inflammatory behaviour $(18,21,34,35)$. To date, no data from genetic studies have been published regarding elderly onset IBD variants to further define the contribution of specific gene associations with elderly onset IBD; however, the role of genetic factors is believed to be greater in pediatric-onset than in late-onset IBD (18). It has also been found that older patients with IBD may have an increased susceptibility to gastrointestinal infection because the response to stress in the setting of acute inflammation may be altered or blunted $(28,30,36)$.

There are some key features considered for elderly onset CD: inflammatory disease behaviour, colonic or ileocolonic disease location, uncommon family history of IBD, and reduced progression to penetrating or stricturing disease phenotypes (37). Prompted by the lack of data from Latin America evaluating the clinical behaviour of $\mathrm{CD}$ in the elderly, the aim of the present study was to evaluate the clinical course of elderly compared with younger-onset $\mathrm{CD}$ in the Mexican population.

\section{METHODS}

The present analysis was a retrospective case-control study that included 132 patients with histopathological diagnosis of CD between 1983 and 2013 in the IBD clinic of a tertiary care centre (National Institute of Medical Sciences and Nutrition "Salvador Zubirán", Mexico). Clinical records were reviewed and a database including the following variables was constructed: sex, age, place of birth, place of residence, weight, height and body mass index; family history of IBD and family or personal history of other immune-mediated diseases; pack-years of smoking (number of cigarettes smoked daily multiplied by the years of smoking divided by 20); history of appendectomy or tonsillectomy; intake of nonsteroidal anti-inflammatory drugs; thrombosis and its location (upper limbs, lower limbs, pulmonary thromboembolism, acute coronary syndrome or vascular brain disease); age at diagnosis; disease phenotype (inflammatory, stricturing or fistulizing); location (terminal ileum, ileocolonic, colonic, upper digestive tract); clinical course (initially active followed by long-term remission, intermittent activity (less or one relapse a year) or continuous activity ( $\geq 2$ relapses per year); extraintestinal manifestations such as arthritis, arthralgia, ankylosing spondylitis, sacroiliitis, sclerosing cholangitis, pyoderma gangrenosum, erythema nodosum or uveitis; number of hospitalizations; treatment response and reasons for lack of response response and surgical treatment. Other variables included were: postsurgical recurrence; current $\mathrm{CD}$ treatment; and clinical activity or remission of the disease at the time of evaluation. The present research was approved by the local ethics committee.

\section{Statistical analysis}

Demographic, clinical, and laboratory characteristics are presented as mean $\pm S D$, median and range. The Fisher's exact probability test was used to compare categorical variables when the number of expected subjects was $<5$ and by the $\chi^{2}$ test otherwise. The unpaired $t$ test was used to compare differences in the means of continuous variables. Nonparametric variables in independent samples were compared using the Mann-Whitney U test. ORs and 95\% CIs were calculated using univariate and multivariate analyses adjusted for age, sex, extent of disease, Mayo Score, C-reactive protein level and current medical treatment. $\mathrm{P} \leq 0.05$ was considered to be statistically significant and Bonferroni correction for $\mathrm{P}$ value was applied for multiple comparison calculated as $\alpha / \mathrm{n}$. All statistical analyses were performed using SPSS version 17.0 (IBM Corporation, USA).

\section{RESULTS}

A total of 132 patients were evaluated 73 (55.3\%) men and 59 (44.7\%) women divided in two groups: $27(20.5 \%)$ who were diagnosed at $>60$ years of age (cases) and $105(79.5 \%)$ who were diagnosed at $\leq 60$ years of age (controls). Detailed demographic and clinical characteristics are summarized in Table 1 and 2, respectively.

\section{CD patients $>60$ years of age}

From the elderly patients, the case group consisted of 27 individuals (10 men and 17 women). The presence of steroid dependency was $3.8 \%$ and steroid resistance $0.8 \%$; thiopurine-resistance $0.8 \%$ and intolerance to thiopurines $2.3 \%$; and $72.7 \%$ undewent intestinal surgical resection. The reasons for surgery were bowel fibrostenotic stricturing $(33.7 \%)$, bowel perforation $(12.7 \%)$, intra-abdominal abscess $(10.3 \%)$, penetrating disease $(9 \%)$, dysplasia $(5 \%)$, cancer $(1.5 \%)$ and toxic megacolon $(0.5 \%)$.

\section{CD patients $\leq 60$ years of age}

The control group included 105 patients (63 men and 42 women). The presence of steroid dependency was $18.5 \%$ and steroid-resistance $7 \%$; thiopurine resistance $15 \%$ and intolerance to thiopurines $2.5 \%$. All patients underwent intestinal surgical resection for the following reasons: bowel fibrostenotic stricturing $(35.2 \%)$, penetrating disease (28.57\%), intra-abdominal abscess (20.5\%), bowel perforation (10.5\%), dysplasia $(2.3 \%)$, cancer $(1.5 \%)$ and toxic megacolon $(1.43 \%)$.

Factors influencing the clinical course of CD in elderly patients The univariate analysis found that the following factors influenced the clinical course of CD in elderly patients: female sex (OR 2.55 [CI 95\% 1.06 to 6.10]; $\mathrm{P}=0.02$ ); a less frequent colonic location ( $\mathrm{OR}=0.22$ CI 95\% CI 0.03 to 0.89]; $\mathrm{P}=0.02$ ); mild clinical behaviour of disease (OR 10.08 [95\% CI 3.74 to 27.17]; $\mathrm{P}=0.0001$ ) and a better response to the medical treatment (OR 2.85 [95\% CI 95\% 1.08 to 7.48]; $\mathrm{P}=0.02$ ), frequent use of sulfasalazine (OR $4.4695 \% \mathrm{CI} 1.22$ to 16.28]; $\mathrm{P}=0.03$ ); low use of azathioprine (OR 0.38 [95\% CI 95\% 0.13 to 1.03$] ; \mathrm{P}=0.04)$ and higher clinical remission rate (OR $4.96[95 \%$ CI 1.70 to 14.48 ]; $\mathrm{P}=0.002$ ) (Table 3 ).

Significant statistical trends were found in the following factors: elderly patients present pulmonary thromboembolism more frequently (OR 6.53 [95\% CI 1.01 to 40.67]; $\mathrm{P}=0.05$ ), as well as a predominant terminal-ileum location (OR 2.03 [95\% CI 0.83 to 4.94]; P=0.09) and a more common inflammatory pattern (OR 0.48 [95\% CI 0.18 to 1.24$]$; $\mathrm{P}=0.09$ ). 
TABLE 1

Demographic variables of patients with Crohn disease

\begin{tabular}{lcc}
\hline Variable & $\begin{array}{c}\text { Cases } \\
(\mathbf{n = 2 7})\end{array}$ & $\begin{array}{c}\text { Controls } \\
(\mathbf{n = 1 0 5 )}\end{array}$ \\
\hline Sex & $10(37)$ & $63(59.05)$ \\
$\quad$ Male & $17(63)$ & $42(40)$ \\
$\quad$ Female & $0(0)$ & $1(0.95)$ \\
Family history of inflammatory bowel disease & $10(37.03)$ & $47(44.76)$ \\
Smoker & $3(11.11)$ & $13(12.38)$ \\
Autoimmune concomitant disease & $7(25.92)$ & $24(22.85)$ \\
Appendectomy & $3(11.11)$ & $18(17.14)$ \\
Tonsillectomy & &
\end{tabular}

Data presented as $n$ (\%)

In the multivariate analysis, the following factors influenced the clincal course of $\mathrm{CD}$ in elderly patients: a less frequent colonic location $(\mathrm{P}=0.021, \mathrm{OR}=0.130)$, a mild clinical course of disease $(\mathrm{P}=0.0001$, $\mathrm{OR}=0.151)$, less use of azathioprine $(\mathrm{P}=0.027, \mathrm{OR}=0.255)$ and inflammatory pattern $(\mathrm{P}=0.01, \mathrm{OR}=0.193)$.

\section{DISCUSSION}

The present study clearly showed a milder clinical course of CD in elderly patients, and was the first performed in the Latin American population. We found that women were predominantly affected, similar to a previous study (the EPIMAD registry [19]) and one study from the United States Military Health Care Population (38). Smoking was associated with increased risk for $\mathrm{CD}$ and worse outcomes over the disease course $(18,39,40)$ and, interestingly, our study found a higher proportion of smoking patients in the young group than in the elderly group, which could have also influenced the different outcomes. In the present study, CD patients had a less frequent colonic location and had a more common inflammatory pattern, compared with the French registry, which found that pure colonic disease and inflammatory behaviour were the most frequent phenotypes (14). A study from Hungary (41) found pure colonic disease and a more common stenosing pattern. A retrospective study concluded that older and younger patients underwent surgery in similar percentages ( $83 \%$ versus $77 \%$ ) (42), a finding similar to that reported in our population (66.6\% versus $74.28 \%)$.

The elderly patients in the present study exhibited mild clinical disease behaviour, characterized by initially active disease followed by longterm clinical remission, better response to medical treatment and more use of sulfasalazine and less use of azathioprine. These findings were also reported in other studies. For example, the Hungarian study (41) found that their elderly population required less systemic steroids compared with their younger groups. A French study (43) concluded that immunosuppressants were more frequently required in the childhoodonset group than in the elderly onset patients. In this study, it was also found that older adults were less likely to require immunosuppressants or readmission for CD flares compared with younger patients (44). It has even been concluded that corticosteroid response is similar in older and younger patients hospitalized for IBD, but older corticosteroidresponsive patients are less likely to be treated with an anti-tumour necrosis factor agent than younger patients (45). Furthermore, care providers should be aware of polypharmacy and its potential for drug interactions because it has been shown that the prevalence of medication use is higher among patients with IBD than matched members of the general population, particularly the use of analgesic and psychiatric drugs (46). Regarding the extraintestinal manifestations of IBD, thromboembolic events represent a major cause of morbidity and mortality $(47,48)$, and it is known that IBD is an independent risk factor for thromboembolic phenomena (49). One study also found a more frequent prevalence of venous thromboembolism (TE) in elderly patients with IBD (6.15\%) compared with the control group (1.62\%) (50). This correlates with the fact that our elderly patients tended to present with pulmonary TE more frequently. Other studies have concluded that the most frequent thromboembolic complications are
TABLE 2

Clinical characteristics of Crohn disease (CD) patients

\begin{tabular}{|c|c|c|}
\hline Variable & Cases $(n=27)$ & Controls $(n=105)$ \\
\hline \multicolumn{3}{|l|}{ CD pattern } \\
\hline Inflammatory & $7(25.92)$ & $44(41.9)$ \\
\hline Fistulizing & $10(37.03)$ & $30(28.57)$ \\
\hline Stricturing & $10(37.03)$ & $37(35.23)$ \\
\hline \multicolumn{3}{|l|}{ CD location } \\
\hline Terminal ileum & $11(40.74)$ & $26(24.76)$ \\
\hline Ileocolonic & $12(44.44)$ & $47(44.76)$ \\
\hline Colonic & $2(7.4)$ & $27(25.71)$ \\
\hline Upper digestive tract & $2(7.4)$ & $7(6.6)$ \\
\hline \multicolumn{3}{|l|}{ Clinical course } \\
\hline $\begin{array}{l}\text { Initially active followed by long-term } \\
\text { remission }\end{array}$ & $19(70.37)$ & $21(20)$ \\
\hline Intermittent activity & $5(18.51)$ & $51(48.57)$ \\
\hline Continuous activity & $2(7.4)$ & $27(25.71)$ \\
\hline \multicolumn{3}{|l|}{ Extraintestinal manifestations } \\
\hline Arthritis & $1(3.7)$ & $6(5.71)$ \\
\hline Arthralgias & $3(11.11)$ & $23(21.9)$ \\
\hline Ankylosing spondylitis & $4(14.81)$ & $8(7.61)$ \\
\hline Sclerosing cholangitis & $0(0)$ & $1(0.95)$ \\
\hline Pyoderma gangrenosum & $0(0)$ & $3(2.85)$ \\
\hline Erythema nodosum & $0(0)$ & $2(1.9)$ \\
\hline Uveitis & $1(3.7)$ & $0(0)$ \\
\hline Lack of response to medical treatment & $10(37.03)$ & $70(66.6)$ \\
\hline Surgical treatment & $18(66.6)$ & $78(74.28)$ \\
\hline Postsurgical recurrence & $1(3.7)$ & $10(9.52)$ \\
\hline \multicolumn{3}{|l|}{ Current treatment } \\
\hline Sulfasalazine & $4(14.81)$ & $6(5.71)$ \\
\hline Mesalazine & $4(14.81)$ & $23(21.9)$ \\
\hline Azathioprine & $6(22.22)$ & $31(29.52)$ \\
\hline Prednisone & $4(14.81)$ & $25(23.8)$ \\
\hline Methotrexate & $0(0)$ & $1(0.95)$ \\
\hline Biologic therapy & $0(0)$ & $2(1.9)$ \\
\hline
\end{tabular}

Data presented as $n(\%)$

TABLE 3

Factors influencing the course of Crohn disease in the elderly population

\begin{tabular}{lrr}
\hline Variable & Univariate analysis & Multivariate analysis \\
\hline Female sex & $\mathrm{P}=0.02$ & $\mathrm{P}=0.54$ \\
$\mathrm{OR}=2.55$ & \\
$\mathrm{P}=0.02$ & $\mathrm{P}=0.03$ \\
$\mathrm{OR}=0.22$ & $\mathrm{OR}=0.13$ \\
Mild clinical course of disease & $\mathrm{P}=0.0001$ & $\mathrm{P}=0.0001$ \\
& $\mathrm{OR}=10.08$ & $\mathrm{OR}=0.15$ \\
Response to medical treatment & $\mathrm{P}=0.02$ & $\mathrm{P}=0.31$ \\
& $\mathrm{OR}=2.85$ & \\
Use of sulfasalazine & $\mathrm{P}=0.03$ & $\mathrm{P}=0.54$ \\
& $\mathrm{OR}=4.46$ & \\
Use of azathioprine & $\mathrm{P}=0.04$ & $\mathrm{P}=0.02$ \\
& $\mathrm{OR}=0.38$ & $\mathrm{OR}=0.25$ \\
Clinical remission & $\mathrm{P}=0.002$ & $\mathrm{P}=0.22$ \\
& $\mathrm{OR}=4.96$ & \\
\hline
\end{tabular}

deep vein thromboses and pulmonary emboli, and that this event can occur as a postsurgical complication or spontaneous event (48).

This less agressive clinical behaviour is gradually occupying an important place among the diverse factors that influence the decisionmaking process regarding the therapeutic approach to an elderly patient 
diagnosed with CD. Nevertheless, it should not be considered without taking into account all other aspects that play a role in each specific case. For example, one current approach to drug therapy in the elderly is to 'start low; go slow' and then reassess their candidacy for more aggressive therapy (biologics, apheresis, surgery), and not treat or exclude patients on the basis of age alone (51). In conclusion, elderly patients with CD had a mild disease course characterized by long-term remission, less use of aggressive therapy, such as thiopurines and anti-tumour necrosis factor agents, and better response to medical treatment.

DISCLOSURES: The authors have no financial disclosures or conflicts of interest to declare.

\section{REFERENCES}

1. Shanahan F. The microbiota and inflammatory bowel disease: Friend, bystander and sometime villain. Nutr Rev 2012;70:S31-S37.

2. 2014 World Population Data Sheet. Population Reference Bureau. <www.prb.org/pdf14/2014-world-population-data-sheet_eng.pdf> (Accesed October 11, 2014).

3. United Nations. Population ageing and sustainable development. Department of Economic and Social Affairs. <www.un.org/en/ development/desa/population/publications/ pdf/popfacts/ PopFacts_2014-4.pdf > (Accesed October 11, 2014).

4. World Health Organization. Good Health adds life to years. Global Brief for World Health Day 2012. <http://whqlibdoc.who.int/ hq/2012/WHO_DCO_WHD_2012.2_eng.pdf?ua=1> (Accesed October 11, 2014)

5. Proyecciones de la población de México 2005-2050. Consejo Nacional de Población.<www.conapo.gob.mx/es/CONAPO/ Documento_Metodologico_Proyecciones_2010_2050 > (Accesed October 13, 2014)

6. Wiener JM, Tilly J. Population ageing in the United States of America, International Epidemiological Association 2002. Int J Epidemiol 2002;31:776-781.

7. Molodecky NA, Soon IS, Rabi DM, et al. Increasing incidence and prevalence of the inflammatory bowel disease with time, based on systematic review. Gastroenterology 2012;142:46-54.

8. Katz S, Pardi DS. Inflammatory bowel disease of the elderly: Frequently asked questions (FAQs). Am J Gastroenterol 2011;11:1889-97.

9. Kelsen J, Baldassano RN. Inflammatory bowel disease: The difference between children and adults. Inflamm Bowel Dis 2008;14:S9-S11.

10. Travis S. Is IBD different in the elderly? Inflamm Bowel Dis 2008;14:S12-S13.

11. Bernstein CN, Wajda A, Svenson LW, et al. The epidemiology of inflammatory bowel disease in Canada: A population-based study. Am J Gastroenterol 2006;101:1559-68.

12. Loftus EV Jr, Silverstein MD, Sandborn WJ, et al. Crohn's disease in Olmsted County, Minnesota, 1940-1993: Incidence, prevalence, and survival. Gastroenterology 1998;114:1161-8.

13. Loftus EV Jr, Silverstein MD, Sandborn WJ, et al. Ulcerative colitis in Olmsted County, Minnesota, 1940-1993: Incidence, prevalence, and survival. Gut 2000;46:336-43.

14. Charpentier C, Salleron J, Savoye G, et al. Natural history of elderly-onset inflammatory bowel disease: A population-based cohort study. Gut 2013;63:423-4.

15. Mamula P, Telega GW, Markowitz JE, et al. Inflammatory bowel disease in children 5 years of age and younger. Am J Gastroenterol 2002;97:2005-10

16. Shivananda S, Lennard-Jones J, Logan R, et al. Incidence of inflammatory bowel disease across Europe: Is there a difference between north and south? Results of the European Collaborative Study on Inflammatory Bowel Disease (EC-IBD). Gut 1996;39:690-7.

17. Gupta N, Bostrom AG, Krischner BS, et al. Gender differences in presentation and course of disease in pediatric patients with Crohn disease. Pediatrics 2007;120:1418-25.

18. Ruel J, Ruane D, Mehandru S, Gower-Rosseau C, Colombel JF. IBD across the age spectrum - is it the same disease? Nat Rev Gastroenterol Hepatol 2014;11:88-98.

19. Gower-Rousseau C, Vasseur F, Fumery M, et al. Epidemiology of inflammatory bowel diseases: New insights from a French population-based registry (EPIMAD). Dig Liver Dis 2013;45:89-94.

\section{CONCLUSIONS}

Elderly patients had a less aggressive clinical course compared with younger patients, and commonly achieved remission without the need of escalating the treatment beyond aminosalycilates.

There are no data from Latin America that evaluate the clinical behaviour of CD in elderly patients. The present study showed that elderly patients with $\mathrm{CD}$ had a mild clinical course characterized by the lack of escalation to immunosuppressive and anti-tumour necrosis factor therapy, as well as long-term remission.
20. Guariso G, Gasparetto M, Visonà Dalla Pozza L, et al. Inflammatory bowel disease developing in paediatric and adult age. J Pediatr Gastroenterol Nutr 2010;51:698-707.

21. Vernier-Massouille G, Balde M, Salleron J, et al. Natural history of pediatric Crohn's disease: A population-based cohort study. Gastroenterology 2008;135:1106-13.

22. Heyman MB, Kirschner BS, Gold BD, et al. Children with earlyonset inflammatory bowel disease (IBD): Analysis of a pediatric IBD consortium registry. J Pediatr 2005;146:35-40.

23. Paul T, Birnbaum A, Pal DK, et al. Distinct phenotype of early childhood inflammatory bowel disease. J Clin Gastroenterol 2006;40:583-6.

24. Langholz E, Munkholm P, Krasilnikoff PA, Binder V. Inflammatory bowel diseases with onset in childhood. Clinical features, morbidity, and mortality in a regional cohort. Scand J Gastroenterol 1997;32:139-47.

25. Freeman HJ. Comparison of longstanding pediatric-onset and adultonset Crohn's disease. J Pediatr Gastroenterol Nutr 2004;39:183-6.

26. Müller KE, Lakatos PL, Arató A, et al. Incidence, Paris classification and follow-up in a nationwide, incident cohort of pediatric patients with inflammatory bowel disease. J Pediatr Gastroenterol Nutr 2013;57:576-82.

27. Britton E, McLaughlin JT. Ageing and the gut. Proc Nutr Soc 2013;72:173-7.

28. Schiffrin EJ, Morley JE, Donnet-Hughes A, Guigoz Y. The inflammatory status of the elderly: The intestinal contribution. Mutat Res 2010;690:50-6.

29. Biagi E, Candela M, Fairweather-Tait S, Franceschi C, Brigidi P. Aging of the human metaorganism: The microbial counterpart. Age 2012;34:247-67

30. Ha CY, Katz S. Clinical implications of ageing for the management of IBD. Nat Rev Gastroenterol Hepatol 2013;11:128-38.

31. Tremaine WJ, Timmons LJ, Loftus EV Jr, et al. Age at onset of inflammatory bowel disease and the risk of surgery for non-neoplastic bowel disease. Aliment Pharmacol Ther 2007;25:1435-41.

32. Malaty HM, Fan X, Opekun AR, Thibodeaux C, Ferry GD. Rising incidence of inflammatory bowel disease among children: A 12-year study. J Pediatr Gastroenterol Nutr 2010;50:27-31.

33. Charpentier C, Salleron J, Savoye G, et al. Natural history of elderly-onset inflammatory bowel disease: A population-based cohort study. Gut 2013;63:423-32.

34. Kugathasan S, Judd RH, Hoffmann RG, et al. Epidemiologic and clinical characteristics of children with newly diagnosed inflammatory bowel disease in Wisconsin: A statewide populationbased study. J Pediatr 2003;143:525-31.

35. Sauer CG, Kugathasan S. Pediatric inflammatory bowel disease: Highlighting pediatric differences in IBD. Med Clin North Am 2010;94:35-52

36. Cambier J. Immunosenescence: A problem of lymphopoiesis, homeostasis, microenvironment, and signaling. Immunol Rev 2005;205:5-6.

37. Ha C, Katz S. Elderly-onset IBD: A milder disease? Nat Rev Gastroenterol Hepatol 2013;10:264-65.

38. Betteridge JD, Armbruster SP, Maydonovitch C, Verappan GR. Inflammatory bowel disease prevalence by age, gender, race, and geographic location in the U.S. military health care population. Inflamm Bowel Dis 2013;19:1421-7.

39. Clegg A, Young J, lliffe S, Rikkert MO, Rockwood K. Frailty in elderly people. Lancet 2013;381:752-62. 
40. Karczewski J, Poniedzialek B, Rzymski P, Rychlewska-Hanczewska A, Adamski Z, Wiktorowicz $\mathrm{K}$. The effect of cigarette smoking on the clinical course of inflammatory bowel disease. $\operatorname{Prz}$ Gastroenterol 2014;9:153-9.

41. Lakatos PL, David G, Pandur T, et al. IBD in the elderly population: Results from a population-based study in Western Hungary, 1977-2008. J Crohns Colitis 2011;5:5-13.

42. Wagtmans MJ, Verspaget HW, Lamers CB, Van Hogezand RA. Crohn's disease in the elderly: A comparison with young adults. J Clin Gastroenterol 1998;27:129-33.

43. Pigneur B, Seksik P, Viola S, et al. Natural history of Crohn's disease: Comparison between childhood- and adult-onset disease. Inflamm Bowel Dis 2010;16:953-61.

44. Heresbach D, Alexandre JL, Bretagne JF, et al. Crohn's disease in the over- 60 age group: A population based study. Eur J Gastroenterol Hepatol 2004;16:657-64.

45. Weber NK, Bruining DH, Loftus EV Jr, et al. Comparative outcomes of younger and older hospitalized patients with inflammatory bowel disease treated with corticosteroids. Inflamm Bowel Dis 2013;19:2644-51.
46. Buckley JP, Kappelman MD, Allen JK, Van Meter SA, Cook SF. The burden of comedication among patients with inflammatory bowel disease. Inflamm Bowel Dis 2013;19:2725-36.

47. Dolapcioglu C, Soylu A, Kendir T, et al. Coagulation parameters in inflammatory bowel disease. Int J Clin Exp Med 2014;7:1442-8.

48. Talbot RW, Heppell J, Dozois RR, Beart RW Jr. Vascular complications of inflammatory bowel disease. Mayo Clin Proc 1986;61:140-5.

49. Cosnes J, Beaugerie L, Carbonnel F, Gendre JP. Smoking cessation and the course of Crohn's disease: An intervention study. Gastroenterology 2001;120:1093-9.

50. Miehsler W, Reinisch W, Valic E, et al. Is inflammatory bowel disease an independent and disease specific risk factor for thromboembolism? Gut 2004;53:542-8.

51. Suárez FC, Vera Mendoza MI, Amo San Román L, et al. Risk of thromboembolic phenomena in patients with inflammatory bowel disease. Gastroenterol Hepatol 2014;35:634-9. 


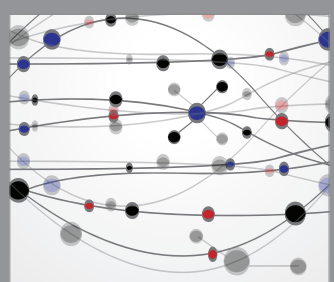

The Scientific World Journal
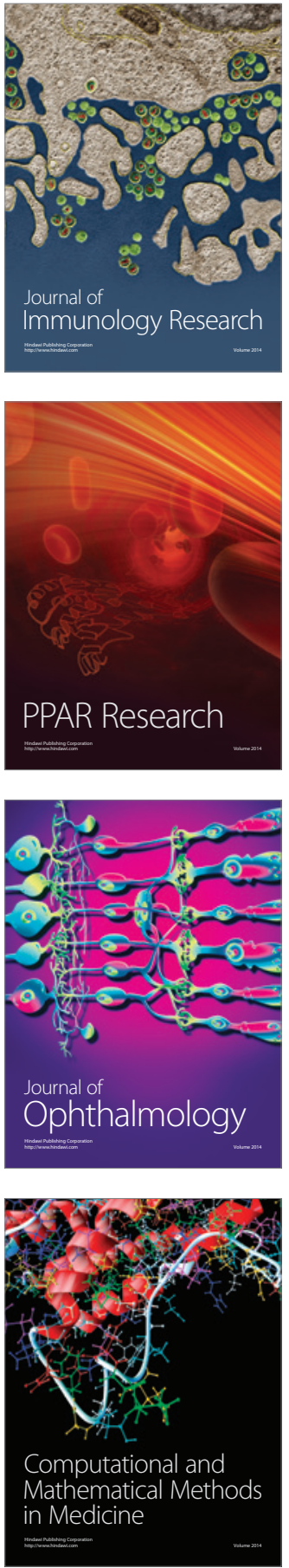

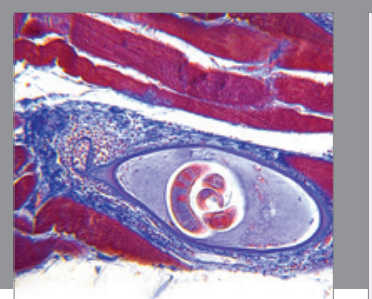

Gastroenterology Research and Practice

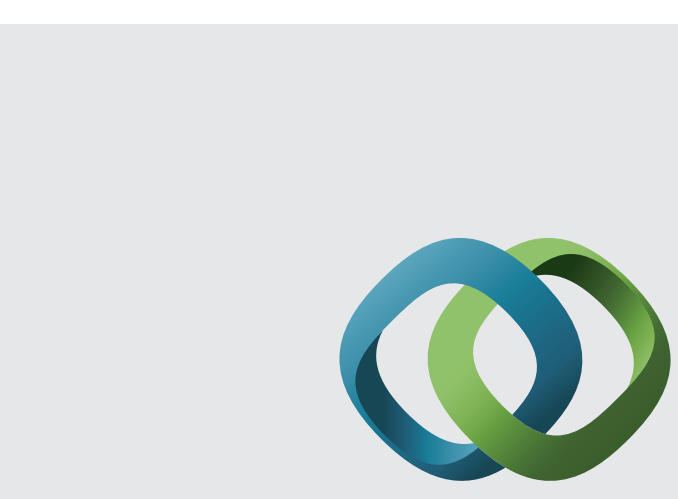

\section{Hindawi}

Submit your manuscripts at

http://www.hindawi.com
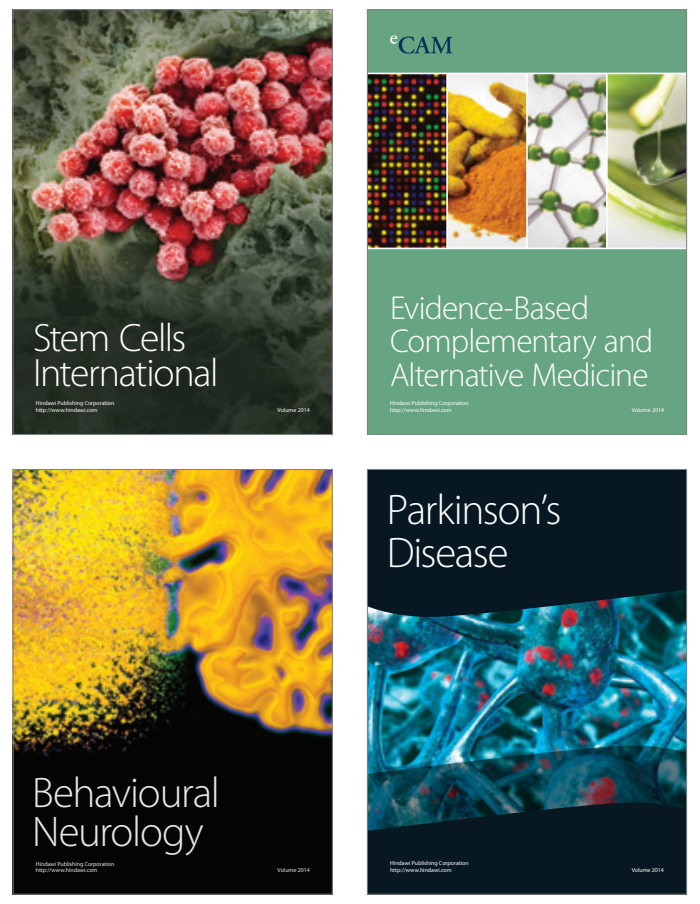
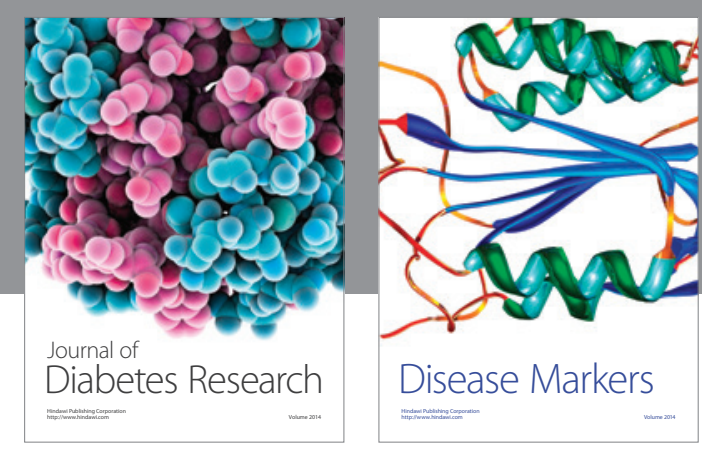

Disease Markers
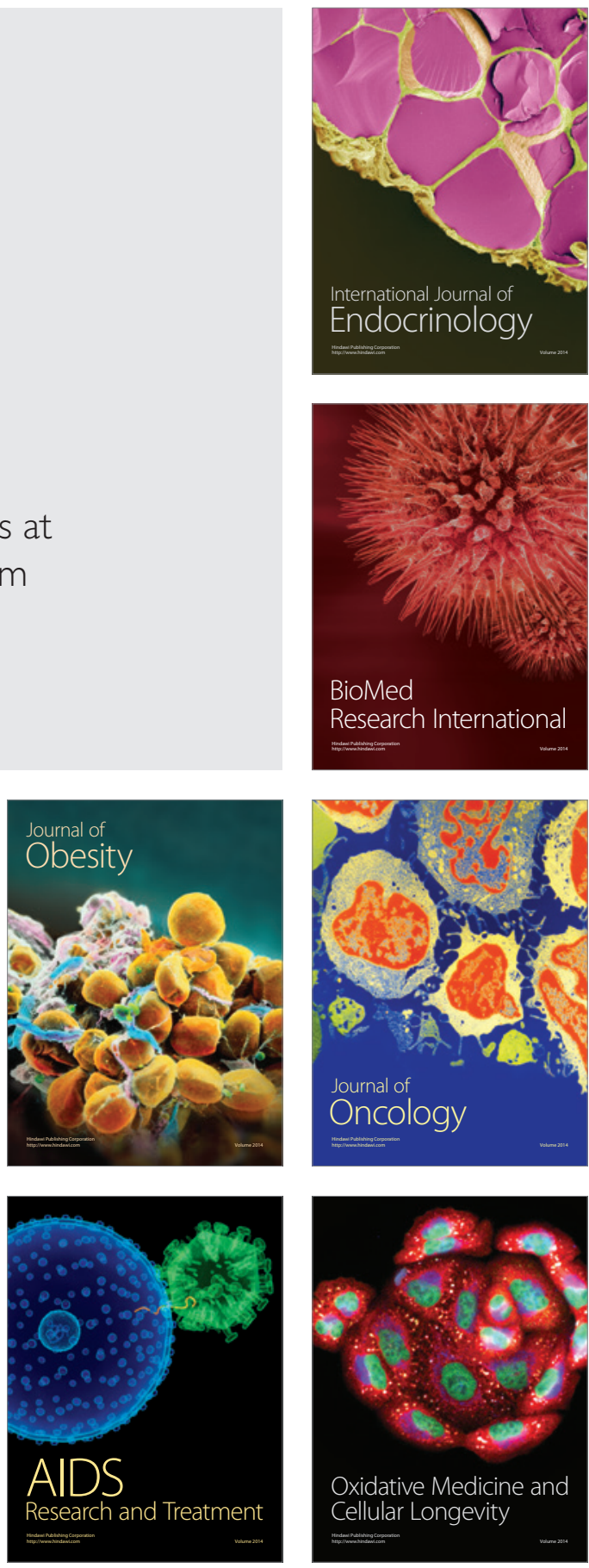